\title{
ON THE CULTURE IN VITRO OF SOME TISSUES OF THE ADULT FROG. ${ }^{1}$
}

\author{
By G. HAROLD Drew, John Lucas Walker Student in the \\ University of Cambridge. \\ From the Pathological Laboratory, Cambridge.
}

(Plates LIV.-LVI.)

METHODS.

THE methods employed in these experiments were mainly those used and described by Carrel and Burrows $\left(1911^{\circ}\right.$ ) in a paper entitled "The Cultivation of Tissues in vitro, and its Technique." Since the successful cultivation of tissues outside the organism is largely dependent on close attention to details of technique, and these details are not entered into in Carrel's and Burrows' paper, the methods employed will here be fully described.

In investigations such as these the highest degree of asepsis has to be preserved when making cultures; accordingly, since a laboratory built on the lines of a modern operating theatre was not available, a room was prepared in the following manner. The floor, tables, walls, ceiling, and windows were thoroughly washed down with hot water, and when dry were coated with an oily preparation, "dust allayer," such as is used for dressing wooden floors; all ventilation shafts were closed and all draughts carefully excluded. The air thus rendered stagnant allows any spores of bacteria or moulds present to settle and adhere to any part of the oily surface of the room with which they may come in contact. Before these precautions were taken a large proportion of the tissue cultures were spoilt owing to the development of species of moulds, the spores of which are easily distributed by the least movement of the air. After treating the room as described, the development of a mould in a culture was of the rarest occurrence, and less than 5 per cent. of the cultures became septic through the growth of bacteria.

Before proceeding to make a series of cultures the room is filled with steam given off from a number of vessels in which water is kept boiling during the whole course of the operation. The floor is freely sprinkled with water, and the work-bench covered with sterile cloths. The condensed steam keeps moist all the surface of the room, and the risk of dust or the spores of bacteria and moulds interfering with the work is minimised.

A necessary preliminary is the preparation of a number of pipettes made from glass tubing : these are drawn out at one end into a capillary, then comes

${ }^{1}$ Received February 25, 1913. 
a dilatation about $2 \frac{1}{2}$ inches long, narrowing down into a second short capillary, ending in a dilatation to which a rubber teat can be fixed. Into these pipettes, sterilised in an iron box by dry heat, melted sterilised vaseline is sucked up and blown out again, so that all the inside of the pipette and about 1 inch of the capillary end on the outside is coated with a very thin layer of vaseline. A number of simple pipettes, ending in capillary tubes, are also made, sterilised, and coated with vaseline as described.

The cultures are made in "hanging drops" on hollow-ground microscopic slides. A number of these slides are placed on the trays of a dry heat steriliser with a cover-glass in position over each hollow; they are then sterilised at about $150^{\circ} \mathrm{C}$. The slides and covers must be chemically clean, and it is important not to sterilise them for long at a temperature much exceeding $150^{\circ} \mathrm{C}$., as the cover-slips tend to devitrify at a surprisingly low temperature.

A quantity of sterile Ringer's solution is prepared, and kept in 1000 c.c. flasks. Instruments are sterilised by boiling in the usual way, and are then transferred to sterile Ringer's solution. Small cork dissecting boards and pins are also sterilised and kept ready for use.

When these preparations have been made, a large frog killed by chloroform is washed in a brisk stream of tap water : it is then placed for about two minutes in a 20 per cent. solution of hydrogen peroxide ( 20 vols.), and finally well washed in sterile water. The use of hydrogen peroxide is specially useful in the case of the frog, the skin of which is covered with a coating of septic mucus, but it is doubtful whether this precaution is really necessary if great care be exercised in opening the abdominal cavity. For this the frog is pinned out on the dissecting board, the skin of the ventral surface reflected with sterile instruments, and the flaps pinned back. The abdominal cavity is opened with fresh sterile instruments and its walls are also reflected and pinned back. The heart is now exposed and the pericardium removed. The ventricle is then lifted up and held in curved forceps, while one of the glass pipettes, the end of which has been broken off so as to leave a sharp point, is plunged through the wall, into the cavity of the ventricle. By means of the rubber teat blood can be sucked up into the pipette, and when the dilated portion is full it is quickly sealed off at both ends, in the blow-pipe, and immediately placed in powdered ice. It is necessary that this operation be performed as rapidly as possible, as at the room temperature frog's blood coagulates in the pipette in a fow minutes, despite the fact that the interior of the pipette is coated with vaseline. Several tubes of blood prepared in this way are packed in powdered ice in the containers of a centrifuge, and are centrifugalised until the corpuscles have separated out leaving a clear colourless plasma. The centrifuge must either be in another room or so screened that the wind caused by its revolution does not tend to disturb any dust lying around.

Considerable difficulty arose in preparing this plasma, on account of the great variation in the coagulability of the blood of individual frogs: in a certain proportion of cases the blood clotted almost immediately on entering the pipette, in others the plasma refused to clot at all when raised to the room temperature, and when placed in contact with the tissues. Successful cultures were only obtained with plasmata, a drop of which would form on a glass slide a fairly stiff jelly-like clot in under ten minutes at the room temperature.

While the blood is being centrifugalised, the tissue of which it is desired to obtain cultures is removed from the body with sterile instruments, the greatest care being taken to avoid any crushing of the cells. It is transferred to Ringer's solution, and then cut into fragments about the size of a pin's head, in a watch-glass containing Ringer's solution. This operation may be done with a cataract knife, or with very sharp fine-pointed scissors which will not damage the tissue by crushing it.

These fragments of tissue are then placed on the cover-slips of the steril- 
ised slide by means of a very small platinum spatula and platinun needle, or else with a fine pipette; it is important that as little as possible of the Ringer's solution should adhere to the tissue fragments when they are placed on the cover-slips. The tubes of blood are removed from the centrifuge, and one end of a tube is cut off with a sterile glass-knife and immediately embedded in fresh powdered ice; a little of the clear plasma is sucked up into a sterile vaselined pipette, and a drop allowed to fall on each fragment of tissue, where it should form a transparent and moderately firm clot almost immediately. The cover-slips are then inverted and placed in position over the hollow slides, and finally sealed by running melted vaseline round the edges. The cultures are best kept at the room temperature.

It is whilst the fragments of tissue are exposed on the cover-slips, before they are inverted over the hollow slides, that there is the greatest danger of contamination from air-borne organisms. On this account, and in order to avoid injury to the tissues by evaporation, it is well to have the atmosphere of the room saturated with steam, and to perform this part of the operation as quickly as possible.

In the following description of the growth in vitro of various tissues, it must be understood that the assignment of a particular type of cell developing in the cultures to a particular type of normal tissue is largely a matter of supposition. The appearance of a living and growing cell, under conditions in which it can be observed more or less separated from surrounding or overlapping cells, and where it is free to send out processes in any direction, is totally different from that of the fixed and stained preparations usually studied; consequently it may be a matter of considerable difficulty to determine the exact nature of the growing cells.

Attempts to make fixed and stained preparations of growing cultures have, so far, not been very successful. The growing tissues are extremely delicate, and are situated in the centre of the clotted plasma: when treated with any fixing agent, the exterior of the plasma immediately becomes hard and opaque and prevents the fixative penetrating the tissues with sufficient rapidity, so that the more delicate cells, and especially those sending out pseudopodial processes, shrink and show other signs of bad fixation. The best results were obtained by a preliminary fixation with formalin vapour, which has great powers of penetration, followed by treatment with acetic sublimate, but even this method was not really satisfactory. Another difficulty is found in staining fixed preparations, as the coagulated plasma takes on and retains most stains almost as well as any part of the cell structure: the best results were obtained by staining for twenty-four hours in Delafield's hæmatoxylin and then differentiating with acid alcohol, consisting of 2 c.c. of strong hydrochloric acid to 1000 c.c. of 70 per cent. alcohol. Heidenheim's hæmatoxylin also gave fairly good results, but there was a tendency to precipitation in the plasma which often spoilt the preparations. Very weak solutions of lichtgrün F.S., or erythrosin, in 70 per cent. alcohol, were sometimes used as counter-stains, but the coagulated plasma stains deeper with them than does the cytoplasm of the growing cells; this, however, makes the cytoplasm more evident, showing it up as a light area against a more deeply stained background.

Cultures fixed and stained by these methods, whether examined in bulk or in serial sections, did not at best show a fraction of the cytological detail that could be made out by observing the living tissues. The following description of the growth of certain tissues is based entirely on observations of living cultures. 
Living "hanging drop" cultures can be examined under any $\frac{1}{6}$-inch objective having a fair working distance. In many cases where the drop of plasma was not deep it was possible to focus a Leitz $\frac{1}{10}$-inch oil immersion objective, but objectives of higher power could not be employed.

The use of a narrow cone of illumination is unavoidable, since the living cells are unstained and have a refractive index elosely approximating to that of the plasma in which they lie. Artificial light passed through a Gifford screen was found to be the most satisfactory source of illumination: daylight is not suitable for the purpose.

\section{The Growth of Cultures of Spleen.}

Cultures of spleen grew more readily and gave a greater proportion of successful cultures than did any other tissue experimented with.

Within the first hour or so after the plasma has clotted round. a fragnient of spleen, a number of red blood corpuscles and a few leucocytes appear in the immediate neighbourhood of the cut surfaces of the tissue. At the same time a very slight rounding off of any sharp angles of the fragment is noticeable, so that it would seem probable that the tissue contracts a little at first and so squeezes out some of its contained corpuscles. In a small proportion of cultures a very delicate reticulum of threads of fibrin could be seen in the coagulated plasma, and these fine threads sometimes radiated in a fan-shaped way from certain points of the tissue, but in the majority of cultures this reticulum could not be seen, and the coagulum appeared as a perfectly transparent colourless jelly.

After six to twelve hours an active emigration of leucocytes begins: these cells are easily recognisable, they possess a few short and rather blunt pseudopodia, and are in fairly active movement. Camera lucida drawings made at five-minute intervals show that these cells rapidly change their shape, send out fresh pseudopodia and retract others, and also move from place to place. The leucocytes in the immediate neighbourbood of the fragment of spleen are more rounded and show fewer pseudopodia than do those which bave wandered somewhat farther afield. As a rule this emigration of leucocytes ceases after from twenty-four to thirty-six hours. By this time a few of the more active leucocytes may have reached nearly to the margin of the drop of plasma, and all appear to be gradually migrating away from the parent tissue. The protoplasm of these leucocytes usually contains a number of small granules, but the pseudopodia are more often free from this granulation: a rounded or lobed space which is free from granules and can be seen in most of the cells probably corresponds to the nucleus. In a small proportion of the leucocytes a great number of tightly packed, highly refractive granules, with optical properties obviously different from those in the other cells, can be seen; these are probably coarsely granular eosinophil cells. Amoboid movement is more active after the culture has been examined under the microscope for some minutes, and so has been 
exposed to the heat and light concentrated in the focus of the substage condenser.

After from three to five days the cells of the splenic pulp begin to emigrate from the parent tissue and appear in the surrounding plasma (see Plate LIV. Fig. 1). These splenic cells are larger than the leucocytes, and are more actively amœboid; they often send out long delicate pointed pseudopodia, the movements of which can easily be watched under the microscope. The bodies of the cells contain a number of granules of various sizes; definite vacuoles filled with some highly refractive liquid are also often present. As a rule a round or oval space, free from granules, can be distinguished in each cell, and in the centre of this a small round body is often present. This space would appear to correspond to the nucleus, and the central body to the nucleolus. These cells divide by a simple process of constriction and separation of the two halves: division is rapid and may be complete in about ten minutes. It is not preceded by any retraction of the pseudopodia, and it looks rather as if the pseudopodia at opposite ends of the cell, by their contraction, simply pull the body of the cell into two halves. The part played by the nucleus in this division could not be determined, but each of the two halves of the cell shortly after division possesses a clear space which presumably corresponds to a nucleus. This division of the amœboid splenic cells is not of frequent occurrence, and it may be necessary to keep the cells under observation for many hours before one can be seen to divide. Nothing corresponding to mitotic division was noted in these cells.

After from seven to ten days delicate pointed processes begin to protrude from the fragment of spleen tissue; these gradually grow out and can be seen to belong to very large elongated cells crowded with small granules, and possessing a definite nucleus and nucleolus. Plate LIV. Fig. 1 represents the growing margin of a 14-day culture of spleen ; the elongated cells, which are presumably of endothelial origin, can be seen radiating in all directions. At their base these cells are usually connected with the parent tissue or with neighbouring cells by root-like protoplasmic processes, free from granules. The body of the cell contains in its cytoplasm a large number of granules and small vacuoles of various sizes and a clear space corresponding to the nucleus, which is bounded by a faint but definite nuclear membrane. No chromatin network could be seen, but the nucleolus was very distinct and relatively rather large. Distally these cells terminated in long delicate processes free from granules, and at times they performed very slow amoboid movements, elongating or waving slightly from side to side. Occasionally an endothelial cell becomes detached from its neighbours, and may wander free in the plasma; under these conditions its amœboid movements are rather more active, especially under the influence of the warmth and light in the focus of the substage condenser. In some of the cells division of the nucleolus was 
seen to occur; it first elongates, then constricts in the middle, and the two halves after separation migrate to opposite ends of the nucleus. In most cultures a number of endothelial cells containing two nucleoli could be seen.

Many attempts were made to observe the process of cell division, but without much success; that division does occur in cultures was clearly shown by the comparison of a number of camera lucida drawings, made at 24-hour intervals, of the same portion of growing tissne; these showed that certain cells had divided, but they gave no clue as to the method of division. On two occasions what appeared to be the initiation of mitosis and the development of a spindle were observed, but the appearance was so indeterminate that it is impossible to place much reliance on this observation. The process was very slow, and in each case was not complete, owing, probably, to the death of the cell through long exposure to the heat and light in the focus of the condenser while the culture was being kept under observation.

That mitotic division does sometimes occur in these cultures was shown by the examination of serial sections, but owing to the difficulties of rapid fixation already mentioned the cytoplasm of the cells did not show up clearly, and though the fixation of the nuclei themselves was comparatively good, and mitotic figures could occasionally be seen, yet usually it was not possible to be certain to which type of cell the dividing nuclei, as seen in section, belonged.

From the tenth day onwards a number of small spindle-shaped cells, each with a definite oval nucleus and very sharp pointed processes at each end, begin to migrate outwards from the parent tissue (see Plate LIV. Fig. 1). These are probably fibroblasts; they contain no granules in their cytoplasm, and no nucleolus was visible in the nucleus. Division was not observed in these cells, but from their presence in increasing numbers in older cultures there is little reason to doubt that it occurs, and that the increase is not entirely due to continued emigration. The majority of the fibroblasts are spindle-shaped, but many forms occur in which one end is rounded, and others in which three or more pointed processes protrude from the body of the cell. These processes are capable of very slow movement, and in older cultures they tend to join up with similar processes of other fibroblasts, forming a sort of network in which other cells are enclosed.

After about twenty-one days, growth in these cultures became very slow, though increase in the number of fibroblasts in the new tissue continued some time longer. The cultures remained alive for from fifty to fifty-five days, - that is to say, up to the limit of this period the cells which had grown out into the plasma remained capable of performing amcboid movements, and showed no sign of degeneration.

At some period between the fiftieth and fifty-fifth day all the cultures died; death was followed by liquefaction of the coagulated 
plasma and autolysis of the cells. The actual changes occurring at death were watched in several instances. The first change noticeable is the liberation of the granules and small vacuoles from all the cells which bave developed in the culture; at the same time the cells themselves collapse, lose their characteristic shapes, and their nuclei disappear. The liberation of the granules is followed by rapid liquefaction of the coagulated plasma, which is complete in less than an hour after the liberation of the cell granules commenced. This, again, is followed by autolysis of the newly developed cells, and eventually of the parent tissue, so that within less than twelve hours from the commencement of the degenerative change nothing is left of the culture except some cell débris floating in the liquefied clot. From the occurrence of these changes it would seem probable that at a certain period, determined, possibly, either by accumulation of the waste products of metabolism or by a lack of oxygen, the cells growing in cultures liberate some proteolytic enzyme, the precursor of which may be contained in the cell granules.

\section{The Growth of Cultures of Artery.}

Cultures were made from fragments of arterial tissue taken from the truncus arteriosus just beyond its division.

Growth was very slow. During the first three or four days a few leucocytes emigrated from the parent tissue and wandered about in the plasma, but it was not until after the fourteenth day, and often later, that any true growth was noticeable. This was manifested by the emergence from the edges of the tissue of very large cells possessing a definite nucleus and nucleolus, and a large number of granules in their cytoplasm (see Plate LV. Fig. 2). These cells agree so closely in appearance with the cells already described as probably being of endothelial origin in the cultures of spleen, that it is unnecessary to give another description of them. The chief point of difference is that in artery cultures the endothelial cells become detached more readily from the edge of the parent tissue and grow out farther into the plasma, when they often develop very long pointed processes at each end. Occasionally a cell becomes entirely detached from its neighbours, and may then send out irregular pseudopodia capable of amœboid movement, and so may wander in any direction in the plasma. In these cultures the endothelial cells alone grew, so that with the exception of a few emigrated leucocytes all the new tissue consisted of endothelial cells and their processes. A slow but steady growth continued up to about the thirty-fifth day, and by this time, in many cultures, the new cells had arranged themselves round the parent tissue, forming a substantial sheath. In this condition the cells were arranged so that their long axes lay on the circumference of a circle circumscribed about the original fragment of tissue, and their 
processes were interlaced, forming a definite network. In slightly older cultures it seemed as though some hyaline substance had been secreted by the cells, as it was impossible to distinguish the individual cell processes, and they appeared to be embedded in a transparent matrix which formed a relatively thick capsule round the parent tissue. Plate LV. Fig. 2 was drawn from a culture in which growth was slow, but the cells remained distinct, so that their morphological characters could be well seen. This formation of a sheath or capsule did not take place in this culture.

Artery cultures remained alive for from fifty to sixty days. At death the same liberation of granules and rapid autolysis of the tissue that was noted in spleen cultures occurred.

\section{The Growth of Cultures of Cerebrum.}

Out of three sets of fifteen cultures, each made on different occasions, only three showed signs of growth. Since so few cultures were successful, little reliance can be placed on the observations; still, they are perhaps worth mentioning.

No growth was apparent in the cultures until the tenth day, when small cells of irregular shape, having curiously short but sharply pointed pseudopodia, began to emigrate from the tissue (see Plate LV. Fig. 3). These cells contained granules and small bighly refractive vacuoles in their cytoplasm, but no trace of a nucleus could be seen. They tended to become aggregated into snall bunches, often connected with each other by their pseudopodia. Amoeboid movement was very slow, but was definitely present. Cells similar to these could just be distinguished in the parent tissue; they were not visible when the cultures were first made, but it seemed as though the granules developed in these cells after the culture had been made, and that it was by means of these granules that the cells were distinguishable. These cells developed in all the three successful cultures, and it is possible that they may be neuroglia cells, though if so they do not seem to be very typical.

In one of the three successful cultures, shown in Flate LV. Fig. 3, growth of what appeared to be nerve cells took place. Unfortunately, the initial stages of this growth were not observed. After fourteen days, cells having very long slender connecting processes, as shown in Plate LV. Fig. 3, were present, and in each case were connected with the parent tissue by a few delicate processes. A nucleus and nucleolus could be seen in most of these cells, but they were not very distinct. A few minute granules were present in the cytoplasm, chiefly in the neighbourhood of the nucleus, but these were clearly of a different nature from the larger highly refractive granules present in the other cells.

When the particular group of cells shown in Plate LV. Fig. 3 
first came under observation, the two distal cells were not present. Their growth was watched at intervals, and it seemed as though the cell from which they arose first sent out two long processes which gradually thickened at the ends, apparently by a slow streaming of protoplasm along the processes connecting them with the parent cell. If this be the correct interpretation of what occurred, it is difficult to explain the origin of the nuclei which were undoubtedly present in the two distal cells.

These cultures died and underwent autolysis soon after the twentieth day.

\section{The Growth of Cultures of Kidney.}

Cultures of kidney tissue grew faster and more luxuriantly than any other tissue experimented with, but a smaller proportion were successful than was the case with spleen tissue. Some of the fragments of tissue included portions of the ciliated epithelium lining the nephrostomes, and the cilia continued their movement at about the normal rate during the life of the cultures.

During the first few days there was a slight emigration of leucocytes, followed by the development of a large number of small, round, highly refractive cells along the margin of the tissue (see Plate LVI. Figs. 4 and 5). By the seventh day these cells had multiplied greatly. Near the parent tissue they were tightly packed together and usually circular in outline; farther out they were oval or pear-shaped with a less regular outline, and many of them sent out short blunt processes, which showed extremely slow amoboid movement. No nucleus could be seen, but a number of minute granules were present in the cytoplasm; the cells were very easily distinguishable from leucocytes, and were presumably derived from the renal epithelium. By the tenth day endothelial cells, similar to those found in cultures of artery and spleen, began to appear: they developed only from certain points at the margin of the parent tissue, from which they grew out into the plasma.

Plate LVI. Fig. 4 shows under a low power of magnification a culture of kidney tissue after fourteen days' growth. On the left the newly developed cells of the renal epithelium can be seen, though they are not so much in evidence in this culture as in most. On the right a portion of the ciliated epithelium of one of the nephrostomes is shown. The cilia were beating at what, compared with freshly excised portions of similar tissue examined in Ringer's solution, seemed to be about the normal rate. They were sufficiently active to cause a small whirlpool on the plasma, which must have been liquefied in the immediate neighbourhood of the ciliated cells. A few isolated cells kept revolving in this whirlpool. This particular culture lived for thirty-five days, and during all this time the cilia were in active 
motion. The culture survived the jolting and shaking of a railway journey of over two hundred miles, thus showing that the clot as a whole formed a fairly stiff jelly, though there must have been an area of liquefaction around the ciliated cells.

In many of the older cultures, such as that one from which the drawing for Plate LVI. Fig. 5 is made, the large endothelial cells arranged themselves so as to form a sheath surrounding the culture, but at some little distance from it. Columns of cells grew out from certain points in the parent tissue, and then branched in a $T$-shaped manner, the branches from different points joining up so as to form a complete sheath. The space between the sheath and the original fragment of tissue was filled with proliferated cells derived from the renal epithelium.

Kidney cultures lived from thirty-five to forty-five days. As in the case of cultures of other tissues, death was manifested by rapid liquefaction of the clot and autolysis of the cells.

\section{Miscellanéous Observations.}

The frogs used in these experiments belonged to the genus and species, Rana temporaria. They were kept in the laboratory in a cold place, in a cage through which a constant trickle of tap water was allowed to flow. As the season was winter, and the frogs were not fed, they were practically in a condition of hibernation, and it would seem possible that cultures made during the spring and summer, when the animals were not hibernating, might grow considerably faster. Among the stock of frogs two varieties were noticed: in one the prevailing colour was a dark greenish brown, in the other a much lighter yellow; the varieties were quite distinct and showed no grading one into the other. Although this difference was undoubtedly not specific according to zoological classification, and was probably only due to the environment in which the frog had lived, it was found that cultures of the tissues of one variety would not grow in the plasma of the other. With this exception no difference was noticeable in the growth of cultures made with autogenic or homogenic plasmata.

The cultures grew best at the room temperature: incubated at $22^{\circ} \mathrm{C}$. growth was distinctly slowed, and at $37^{\circ} .5 \mathrm{C}$. was inhibited. After twelve hours' exposure to a temperature of $37^{\circ} .5$ C. no sign of growth could be seen even after three months. The fragments of tissue remained unchanged and perfectly preserved in the clotted plasna, with the exception that the hemoglobin in the red blood corpuscles became bleached. Exposure for short periods to a slightly increased temperature certainly accelerated the movements of amœboid cells, but the effect of such temperature variations on the rate of growth was not determined.

A moderate amount of light did not appear to bave any influence 
on the growth of cultures, those kept in the dark and those exposed to daylight in a north window growing, as nearly as could be estimated, at the same rate.

A few cultures were grown successfully in lymph collected aseptically from the lymph sacs of the frog, according to R. C. Harrison's original method, but this was abandoned on account of the difficulty of obtaining lymph of the right degree of coagulability; usually it was too watery and refused to clot, and at other times it was very scanty in amount and would clot immediately it entered the collecting pipette.

No growth was obtained in cultures made in Ringer's solution instead of plasma. A few leucocytes emigrated from the tissue during the first few hours, but degenerative changes in them and in the tissue fragment were apparent after twenty-four hours.

No growth was obtained in cultures made in serum instead of plasma; degenerative changes in the emigrated leucocytes and parent tissue did not set in so soon as was the case when Ringer's solution was used as a culture medium, but were noticeable after seven to ten days. In some cultures of spleen made in serum to which sterilised fibres of cotton wool had been added, so that they might act as a framework for the growing cells, there appeared to be a slight growth of the endothelial cells which stretched themselves along the fibres of cotton, but owing to this it was difficult to distinguish the nature of the cells, and in any case the growth was very slight and was more probably of the nature of an emigration and not a true growth of cells.

In cultures made in serum to which an equal volume of a 2 per cent. solution of agar in Ringer's solution (cooled down to $40^{\circ} \mathrm{C}$. before admixture with the serum), no growth occurred. Leucocytes emigrated into the surrounding jelly and showed amœboid movements for several days, thus proving that the short exposure of the tissue to a temperature of $40^{\circ} \mathrm{C}$., which rapidly fell as the drop cooled, had not caused the death of the culture.

Of any series of cultures made in normal plasma, only a certain proportion grew at all. Thus in spleen cultures about 50 per cent. grew, though each series of cultures was made by cutting a small piece of spleen into fragments, and adding plasma from the same tube of centrifugalised blood to each fragment. As a rule about twenty cultures were made from each tube of blood, and as they were made with fragments of the same piece of spleen, and were as far as possible all made in exactly the same way, it is very difficult to understand this irregularity in growth. Many small variations im technique were tried in order to clear up this matter, but without success, and at present it remains unexplained.

There appears to be a certain optimum size of the tissue fragments from which the most successful cultures can be made: such 
fragments should not be much under $1 \mathrm{~mm}$. nor over $3 \mathrm{~mm}$. in diameter. Large fragments tend to degenerate in the centre where the cells are necessarily shut off, somewhat, from the surrounding plasma, whilst in the case of very small fragments it is probable that such a large proportion of the cells are injured in the process of excision and the subsequent manipulations, that little or no growth can take place in cultures made from them.

\section{REFERENCES.}

Bibliography of some of the more important papers dealing with the growth of tissues in vitro.

1. Beebe and Ewing . . " A Study of the Biology of Tumour Cells," Brit. Metl. Journ., London, 1906, vol. xi. p. 1559.

2. Burrows, M. 'T. . . . "The Growth of Tissues of the Chick Embryo outside the Animal Body, with special reference to the Nervous System," Joum. Exper. Zool., 1911, vol. x. p. 63.

3.

"Rythmische Kontraktionen der isolierten Hertzmuskelzelle ausserhalb des Organismus," München. med. Wchnschr., 1912, No. 27, S. 1473.

4. Carrel, A. . . . . . "Technique for Cultivating a Large Quantity of Tissue," Journ. Exper. Med., Baltimore, 1912 , vol. xv. p. 393.
5. " . . . . "On the Permanent Life of Tissues ontside of the Organism," ibid.,1912, vol. xv. p. 516.
6. . " . . . . "Pure Cultures of Cells," ibid., 1912, vol. xvi. p. 165.
7. Carrel, A., and M. T. "Cultivation of Adult Tissues and Organs Burrows outside the Body," Journ. Am. Med. Assoc., 1910, vol. lv. p. 1379.
8.
9. "
10.
"
"
,
11. " "
12. ", "
13. Carret, A., and INGEBRIGTSEN
14. HADA, $\mathrm{S}$.
"Cultivation of Tissues in Vitro and its Technique," Journ. Exper. Med., Baltimore, 1911, vol. xiii. p. 387 .
"Cultivation in Vitro of the Thyroid Gland," ibid., 1911, vol. xiii. p. 416.
"On the Physiochemical Regulation of the Growth of Tissues; the Effect of Dilution of the Medium on the Growth of the Spleen," ibid., 1911, vol. xiii. p. 562.
"Cultivation in Vitro of Malignant Tumours," ibid., 1911, vol. xiii. p. 571 .
"An Addition to the Technique of the Culti- vation of Tissues in Vitro," ibid., 1911, vol. xiv. p. 244.
R. "The Production of Antibodies by Tissues living outside of the Organism," ibid., 1912, vol. xv. p. 287.
"Die Kultur lebender Körperzellen," Berl. klin. Wchnschr., 1912, No. 1, S. 11.




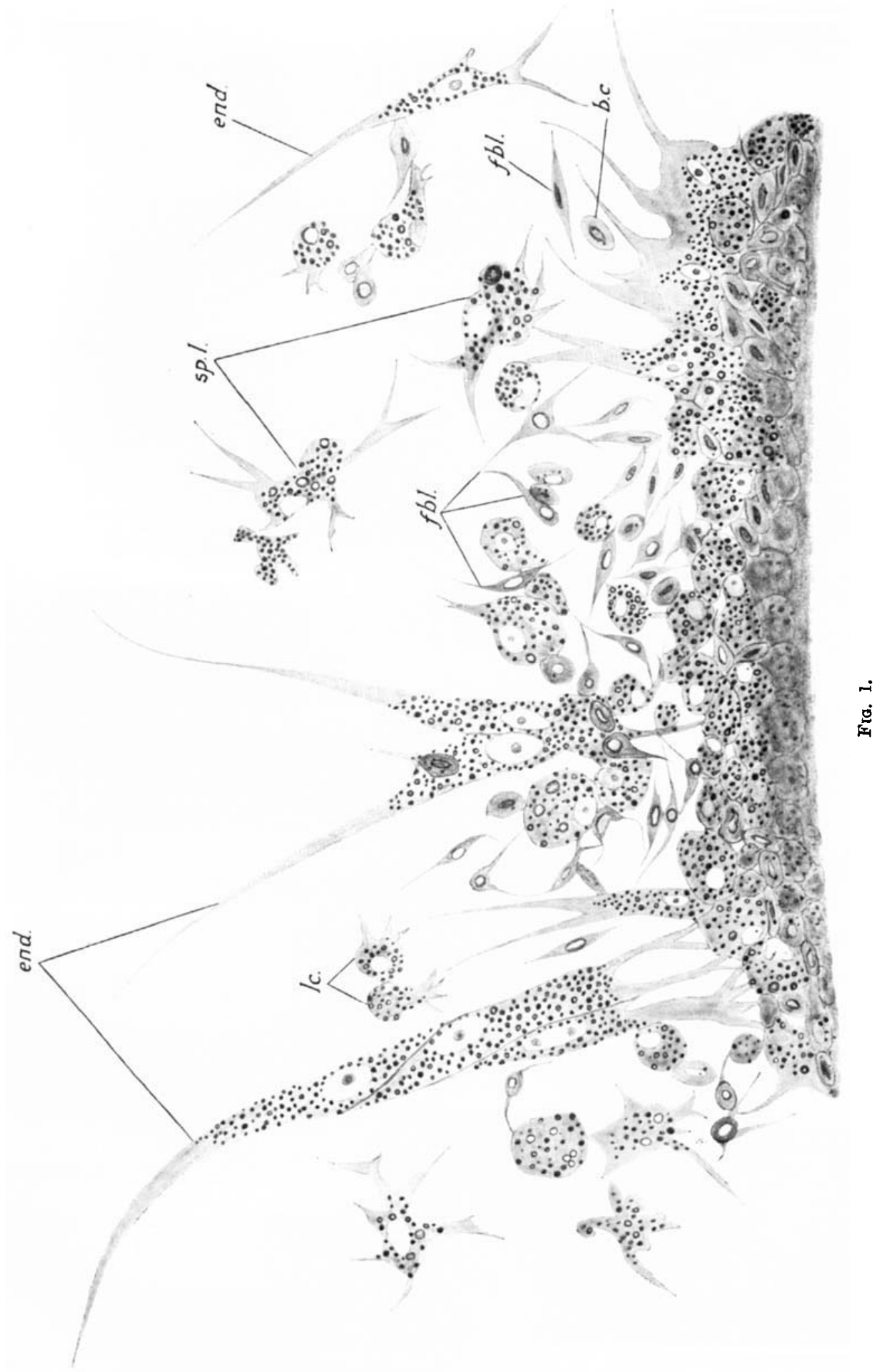




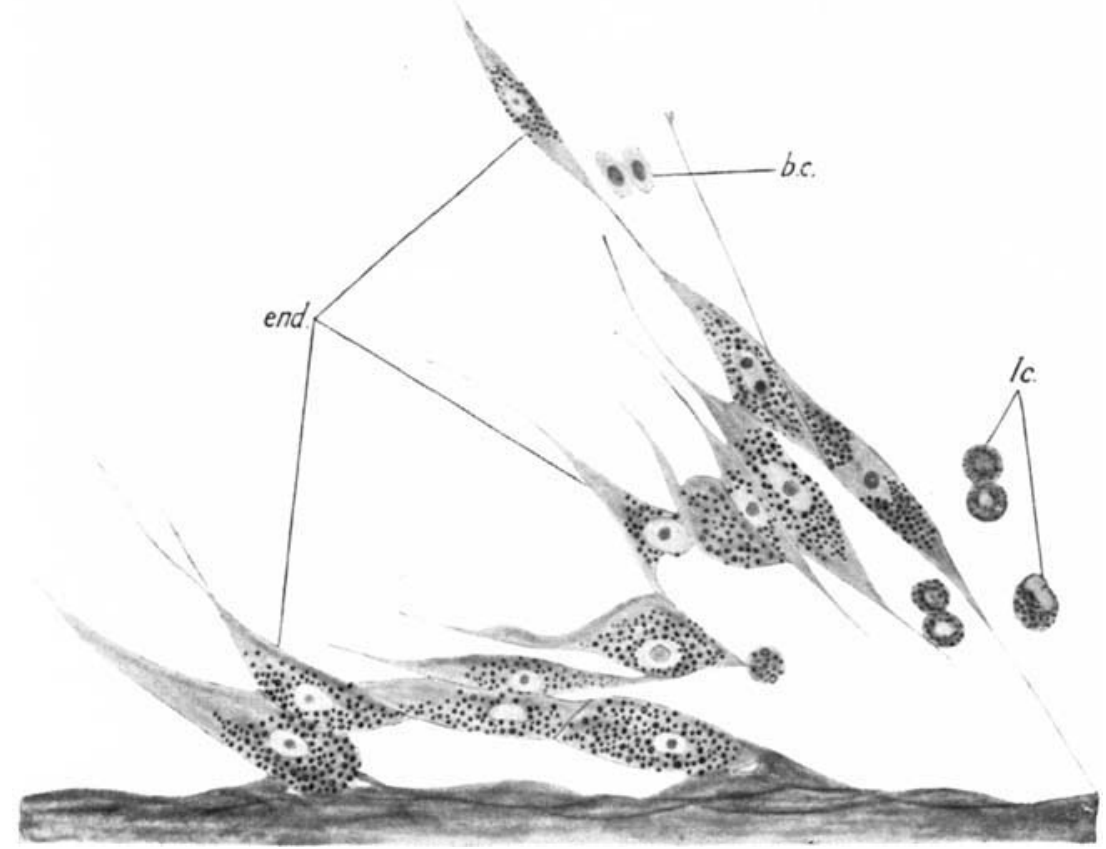

Fig. 2.

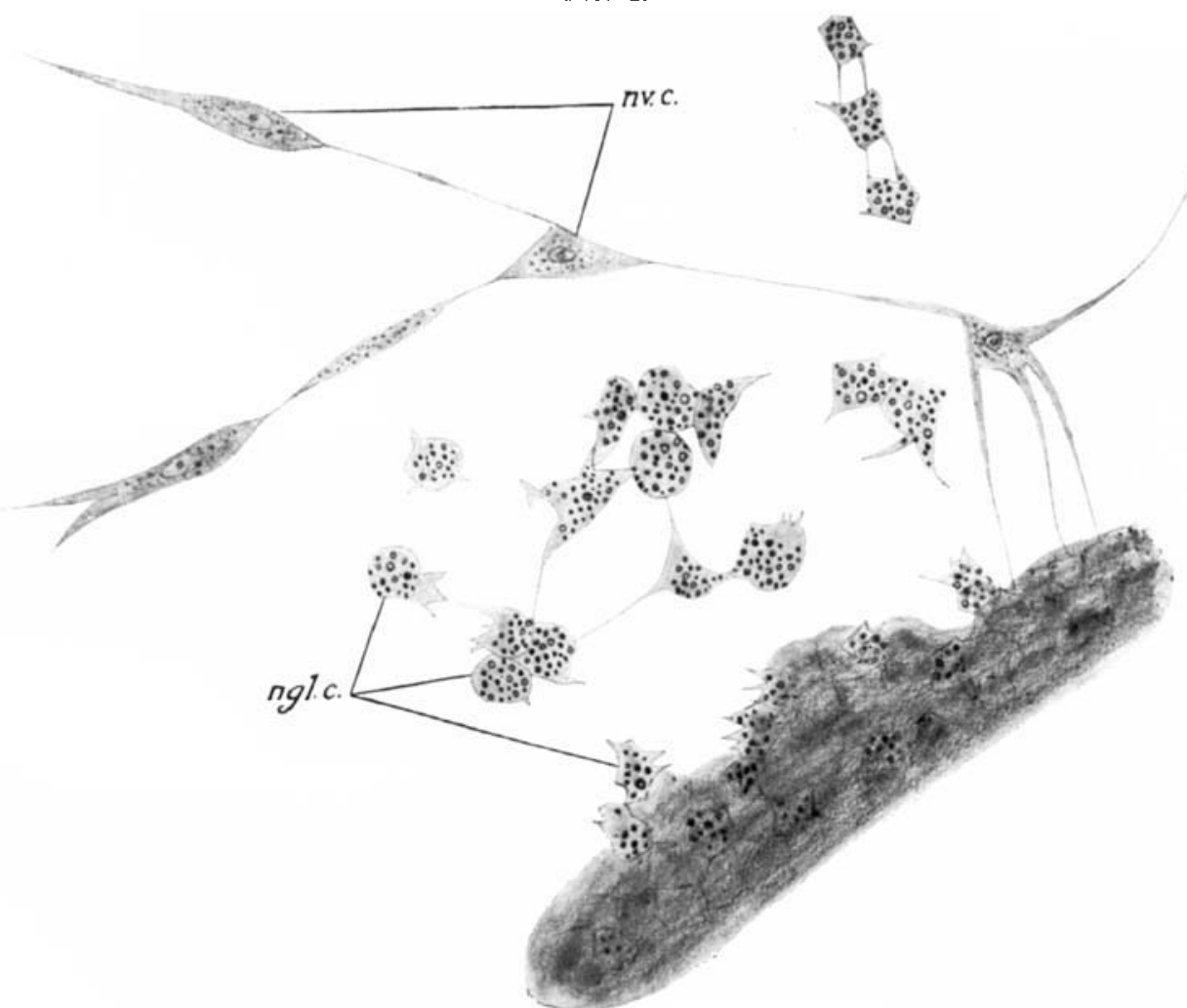

FIG. 3. 


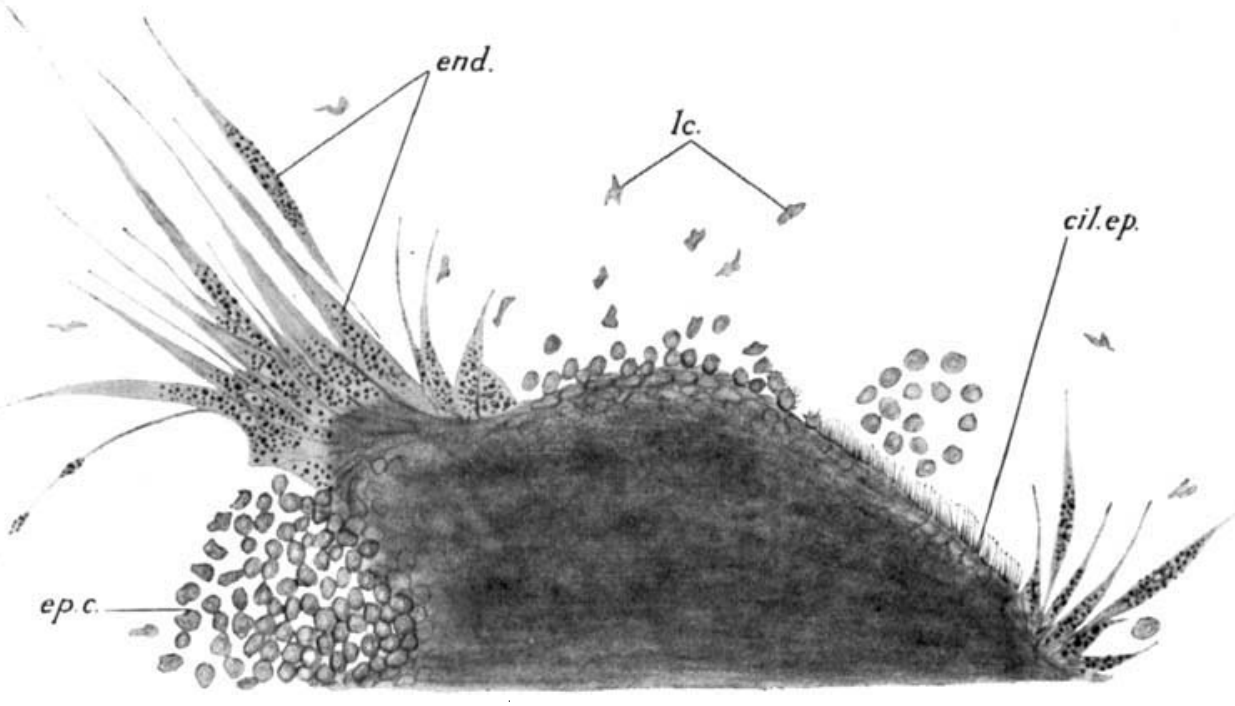

FIG. 4.

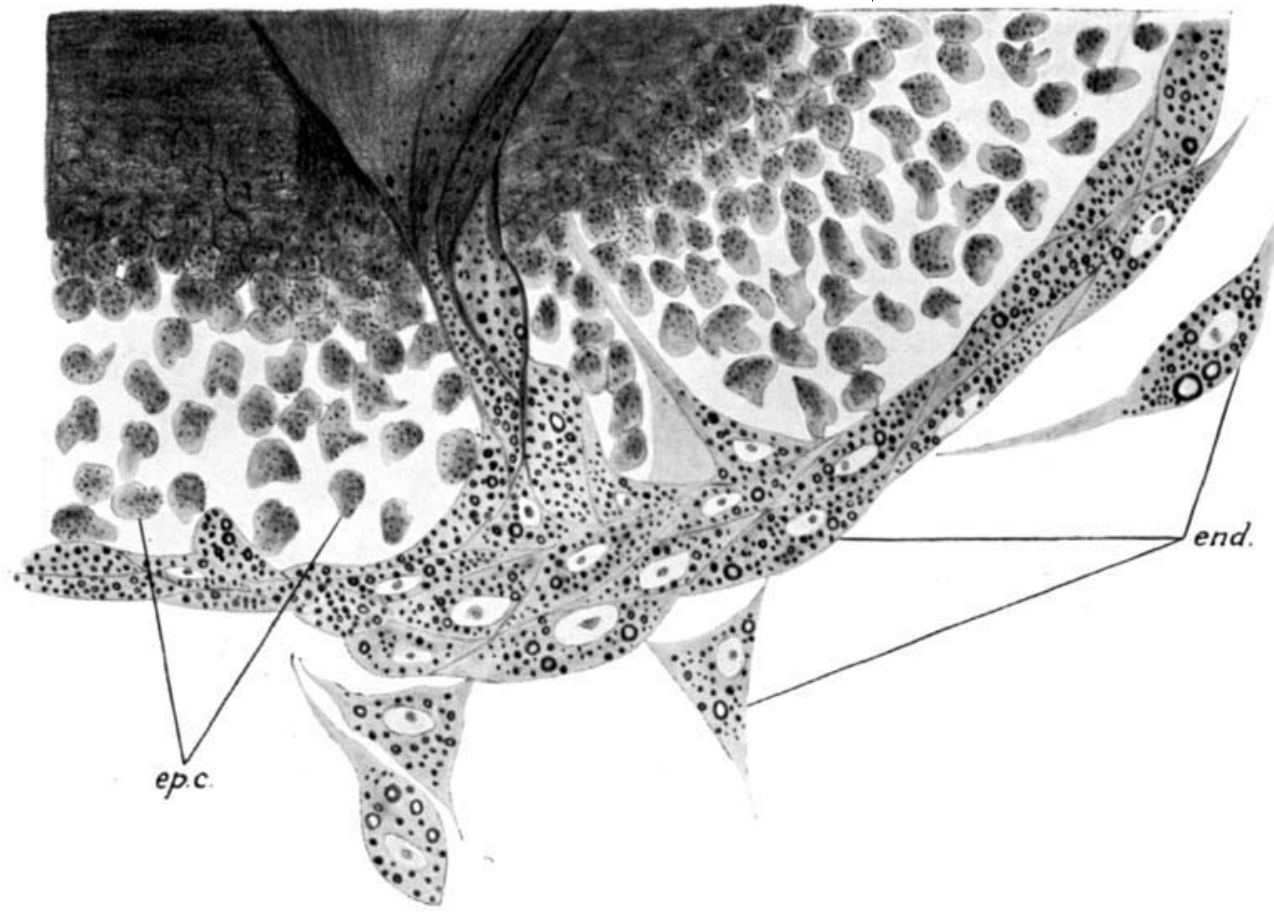

Fig. 5. 
15. Harrison, R. G. . . . "Observations on Living Developing Nerve Fibres," Proc. Soc. Exper. Biol. and Med., 1907, vol, iv. pp. 140-143.

16. " . . . "Embryonic Transplantation and the Development of the Nervous System," Harvey Lectures, 1907-8, Anat. Rec., vol. ii. p. 385.

17. ". . "The Outgrowth of the Nerve Fibre as a Mode of Protoplasmic Movement," Journ. Exper. Zool., 1910, vol. ix. pp. 787-848.

18. Hooker, Davenport . "The Development and Function of the Heart in Fmbryos without Nerves," Proc. Soc. Exper. Biol. and Med., 1910, vol. iv. p. 154.

19. Irgebrigtsen, R. . . . "The Influence of Heat on different Sera as Culture Media for Growing Tissues," Journ. Exper. Med., Baltimore, 1912, vol. xv. p. 397.

20.

"Studies upon the Characteristics of different Culture Media and their Influence upon the Growth of "Tissue outside the Organism," ibid., 1912, vol. xvi. p. 421.

21. Lambert, R. A. . . . . "The Production of Foreign-body Giant Cells in Vitro," Journ. Exper. Med., Baltimore, 1912, vol. xv. p. 510 .

22. Loeb, Leo . . . . "Ueber das Wachstum des Epithels," Arch. f. Entw. Mech., 1912, Bd. xiii. S. 487.

23. OpPEL, A. . . . . . "Ueber die Kultur von Säugetiergewobe ausserhalb des Organismus," ibid., 1912, Bd. xxxiv. S. 132.

24. Wert, G. C. . . . . "Some Observations on the (Culture of) Tissues in Vitro," Journ. Med. Research, Boston, 1912, vol. xxvi. p. 159.

\section{DESCRIPTION OF PLATES LIV-LVI.}

Explanation of leltering:-

b.c. $=$ red blood corpuscle.

cil.cp. $=$ ciliated epithelium.

end. $=$ endothelium

$c p . c .=$ epithelial cells of kidney.

$f t l .=$ fibroblast.

For detailed account of the figures see text. The figures have been drawn as accurately as possible, using a Zeiss camera lucida.

Plate Liv.

FIG. 1.-Spleen of frog, 14-days' culture in plasma. From a drawing. $(\times 450$.

Plate LV.

FiG. 2.-Artery of frog, 40-days' culture in plasma. From a drawing. $(\times 300$.

Fic. 3.-Cerebrum of frog, 14-days' culture in plasma. From a drawing. $(\times 350$.

Piate LVI.

FIG. 4.-Kidney of frog, 14-days' culture in plasma ; the cilia shown in this figure were in active movement. From a drawing. $(\times 130$.

Fic. 5. - Kidney of frog, 40-days' culture in plasma. From a drawing. $(\times 420$. 